\title{
Effect of dietary soyabean hulls and metal-amino acid chelated mineral supplementation on growth performance, nutrient digestibility and noxious gas emission in growing pigs*
}

\author{
Y. Wang, J.H. Cho, Y.J. Chen, J.S. Yoo, H.J. Kim, Y. Huang, \\ S.O. Shin, T.X. Zhou and I.H. Kim ${ }^{1}$ \\ Department of Animal Resources and Science, Dankook University \\ \#29 Ansedong, Cheonan, Chongnam, 330-714, Korea
}

(Received 1 October 2007; revised version 28 January 2008; accepted 8 April 2008)

\begin{abstract}
A $2 \times 2$ factorial design Experiment 1 was conducted in order to characterize the effects of soyabean hulls (control or soyabean hulls diet) and metal-amino acid chelated minerals (MAC) (sulphate or MAC) on growth performance and nutrient digestibility in growing pigs. Forty eight pigs with the initial body weight (BW) $18.0 \pm 1.1 \mathrm{~kg}$ were assigned on the basis of weight and sex to one of four treatments ( 2 pigs/pen, 6 replication pens/treatment, 6 barrows and 6 gilts/treatment). Throughout the experimental period, growth performance was not shown to be affected by dietary treatments. The coefficients of the total tract apparent digestibility of dry matter (DM) and nitrogen (N) remained unaffected by soyabean hulls diets or MAC supplementation. In Experiment 2, four barrows were used in a $4 \times 4$ Latin square design, to determine the effects of soyabean hulls and mineral types on emission of faeces and slurry noxious gas, including ammonia $\left(\mathrm{NH}_{3}\right)$, hydrogen sulphide $\left(\mathrm{H}_{2} \mathrm{~S}\right)$ and mercaptans (R.SH), in growing pigs. Faeces and urine grab samples were collected, and the faeces $(300 \mathrm{~g})$ and slurry (faeces + urine $=150+150 \mathrm{~g}$ ) were mixed, stored, and fermented for $5 \mathrm{~d}$ in order to evaluate noxious gas emission. Pigs fed diets with soyabean hulls tended to have lower $\mathrm{NH}_{3}$ emission from faeces $(\mathrm{P}=0.09)$ than those fed the control diet, but $\mathrm{NH}_{3}$ emission from the slurry was not affected by soyabean hulls diet $(\mathrm{P}=0.12)$. No significant effects on the faeces or slurry $\mathrm{NH}_{3}$ emission were exerted in MAC supplementation treatment. A significant level of interaction between soyabean hulls and MAC was observed both in the faeces and slurry $\mathrm{NH}_{3}$ emission $(\mathrm{P}=0.05, \mathrm{P}=0.01)$. Pigs fed diets with soyabean hulls tend to exhibit lower $\mathrm{H}_{2} \mathrm{~S}$ emission from the slurry $(\mathrm{P}=0.07)$, but significantly lower levels of $\mathrm{H}_{2} \mathrm{~S}$ emission both from faeces and slurry $(\mathrm{P}=0.004, \mathrm{P}=0.02)$ was observed when pigs were fed on MAC diets. The emission of R.SH from faeces significantly decreased $(\mathrm{P}=0.02)$ in MAC supplementation treatments, but not from slurry, and no soyabean hulls effects or interaction were observed in relation to R.SH emission.
\end{abstract}

\footnotetext{
* Supported by the Rural Development Administration of Korea

${ }^{1}$ Corresponding author: e-mail: inhokim@dankook.ac.kr
} 
We conclude that the interaction between dietary soyabean hulls and MAC may have an effect on noxious gas emission. The emission of $\mathrm{NH}_{3}$ from pig faeces could be substantially reduced by diets enriched with soyabean hulls and emission of $\mathrm{H}_{2} \mathrm{~S}$ both from pig faeces and slurry could be reduced by MAC supplementation.

KEY WORDS: ammonia, digestibility, metal-amino acid chelated minerals, soyabean hulls, odorous, pig

\section{INTRODUCTION}

A great deal of concern in recent years has focused on potential environmental hazards and pollution. Emission of noxious gases from pig facilities is one of the principal sources of environmental pollution in pork production, and several kinds of odours have been implicated, including $\mathrm{NH}_{3}, \mathrm{H}_{2} \mathrm{~S}$, R.SH, and volatile organic compounds (Schiffman, 1998). With increasing pressure to sustain and improve the environment, many producers and researchers are currently looking for methods to minimize the environmental impacts of meat production. In the past, a lot of researches have shown that the addition of non-starch polysaccharides (NSP) exerts a positive impact on slurry odour, particularly the production of $\mathrm{NH}_{3}$, without hindering growth performance (DeCam et al., 2001). Ferket et al. (2002) reviewed the nutritional strategies for the reduction of negative emission from nonruminants. They suggested that the noxious gas emission from animals is ultimately associated with nutrient utilization and the intestinal microbiota ecosystem. The addition of NSP source supplementation in the diet was proposed as a method to improve the intestinal microbiota ecosystem and to alter excreta $\mathrm{pH}$, thereby reducing pollution.

Hydrogen sulphide and methyl mercaptan are frequently identified as pig waste constituents and are quantitatively the most important S-containing volatile constituents (Spoelstra, 1980). The reduction of inorganic sulphate to sulphide occurs to a limited extent in nonruminants (Kline et al., 1971). Therefore, it seems that the majority of the production of hydrogen sulphide and other volatile sulphurcontaining gases occurs as the consequence of microbial fermentation during slurry storage. Replacement with non-sulphate minerals has been suggested as another feasible way by which the production of animal sulphur-based gases can be reduced. Therefore, we hypothesized that a high NSP content soyabean hulls diet coupled with non-sulphate minerals (metal-amino acid chelated mineral) could reduce both $\mathrm{NH}_{3}$ and sulphur-based gas production from pig faeces and slurry.

The present study was conducted in order to assess the effects of soyabean hulls diet and MAC supplementation on growth performance, DM and N digestibility, and faecal and slurry noxious gas emission in growing pigs. 


\section{MATERIAL AND METHODS}

The experimental protocols were approved by the Animal Care and Use Committee of Dankook University.

\section{Experiment 1. Growth performance experiment}

Experimental design, animals, housing and diets. A total of 48 pigs (initially $18.0 \pm 1.1 \mathrm{~kg}$ of BW) were used in a 5-week experiment to evaluate the effect of feeding soyabean hulls and MAC on growth performance and nutrient digestibility in growing pigs. The pigs were allotted to treatments by weight with sex ratios equalized in accordance with a completely randomized design, with 2 pigs per pen and 6 replications per treatment. All pigs were housed in environmentallycontrolled rooms with plastic, slatted floors. Each of the pens was equipped with a one-sided self-feeder and a nipple waterer to allow ad libitum access to feed and water throughout all the experimental periods. The target room temperature and humidity were maintained at $25^{\circ} \mathrm{C}$ and $60 \%$, respectively. The dietary treatments included: 1 . basal diet + sulphate minerals, 2 . basal diet + metal-amino acid chelated minerals, 3 . soyabean hulls diet + sulphate minerals and 4 . soyabean hulls diet + metal-amino acid chelated minerals. All diets were formulated to meet or exceed the NRC (1998) recommendations for all nutrients (Table 1) and were fed in meal form.

Sampling and measurements. Individual pig weights were measured at the beginning and end (5 weeks) of the experimental period; feed consumption was also recorded in terms of gain/feed on a pen basis. Growth performance, including average daily gain (ADG), average daily feed intake (ADFI) and gain/feed, was determined at the conclusion of the feeding trial.

The coefficients of total tract apparent digestibility for DM and $\mathrm{N}$ were determined at the end of 5 weeks. Chromic oxide $\left(\mathrm{Cr}_{2} \mathrm{O}_{3}\right)$ was used as an indigestible marker. Pigs were fed on $0.2 \%$ chromic oxide-containing diets for 7 days prior to the collection day, and fresh faecal grab samples were acquired from each pen at $\mathrm{d} 35$. All of the faecal samples, as well as the feed samples, were stored in a refrigerator at $-20^{\circ} \mathrm{C}$ until they could be further analysed. Prior to chemical analysis, the faecal samples were thawed and dried for $72 \mathrm{~h}$ at $70^{\circ} \mathrm{C}$ and subsequently ground in order to pass them through a 1-mm screen. All of the feed and faecal samples were analysed for DM and $\mathrm{N}$ according to AOAC procedures (1995). Chromium was analysed via UV absorption spectrophotometry (Shimadzu, UV-1201, Japan) according to the methods described by Williams et al. (1962). Nitrogen levels were assessed using a Kjeltec 2300 Analyzer (Foss Tecator AB, Hoeganaes, Sweden). 
Table 1. Formular and chemical composition of diets

\begin{tabular}{|c|c|c|}
\hline Item & Control diet & Soyabean hulls diet \\
\hline \multicolumn{3}{|l|}{ Ingredient, $\mathrm{g} / \mathrm{kg}$} \\
\hline maize & 669.1 & 624.0 \\
\hline soyabean meal, dehulled & 150.5 & 154.0 \\
\hline maize gluten & 106.0 & 86.2 \\
\hline soyabean hulls & - & 50.0 \\
\hline molasses & 25.0 & 25.0 \\
\hline tallow & 27.0 & 39.0 \\
\hline difluorinated phosphate & 11.9 & 11.7 \\
\hline calcium carbonate & 4.6 & 4.4 \\
\hline salt & 1.5 & 1.5 \\
\hline L-lysine $\mathrm{HCl}, 78 \%$ & 0.9 & 0.6 \\
\hline DL-methionine, $98 \%$ & - & 0.1 \\
\hline vitamin premix $^{1}$ & 1.0 & 1.0 \\
\hline mineral premix (sulphate or chelated) ${ }^{2}$ & 2.5 & 2.5 \\
\hline \multicolumn{3}{|l|}{ Calculated composition } \\
\hline digestible energy, $\mathrm{MJ} / \mathrm{kg}$ & 14.38 & 14.38 \\
\hline dry matter, $\mathrm{g} / \mathrm{kg}$ & 821.4 & 812.8 \\
\hline crude protein, $\mathrm{g} / \mathrm{kg}$ & 148.5 & 148.5 \\
\hline crude fibre, $\mathrm{g} / \mathrm{kg}$ & 28.5 & 43.3 \\
\hline crude fat, $\mathrm{g} / \mathrm{kg}$ & 30.1 & 29.1 \\
\hline ash, $\mathrm{g} / \mathrm{kg}$ & 26.5 & 27.4 \\
\hline starch, g/kg & 447.8 & 415.3 \\
\hline sugar, $\mathrm{g} / \mathrm{kg}$ & 38.1 & 38.1 \\
\hline $\mathrm{NSP}^{3}, \mathrm{~g} / \mathrm{kg}$ & 278.9 & 302.9 \\
\hline lysine, $\mathrm{g} / \mathrm{kg}$ & 7.3 & 7.3 \\
\hline methionine, $\mathrm{g} / \mathrm{kg}$ & 2.5 & 2.5 \\
\hline cystine, $\%$ & 27.9 & 27.4 \\
\hline methionine + cystine, $\mathrm{g} / \mathrm{kg}$ & 52.6 & 51.7 \\
\hline $\mathrm{Ca}, \mathrm{g} / \mathrm{kg}$ & 7.0 & 7.0 \\
\hline $\mathrm{P}, \mathrm{g} / \mathrm{kg}$ & 5.2 & 5.2 \\
\hline \multicolumn{3}{|l|}{ Analysed composition, $\mathrm{g} / \mathrm{kg}$} \\
\hline crude protein & 149.2 & 147.8 \\
\hline dry matter & 811.4 & 817.8 \\
\hline $\mathrm{Ca}$ & 7.1 & 6.8 \\
\hline $\mathrm{P}$ & 5.3 & 5.2 \\
\hline
\end{tabular}

${ }^{1}$ provided per kg of complete diet, IU: vit. A 4.000, vit. $\mathrm{D}_{3} 800$, vit. E 171 ; mg: vit. K 2, vit. $\mathrm{B}_{2} 4$, vit. $\mathrm{B}_{6} 1$, pantothenic acid 11 , niacin 20 and biotin $0.05 ; \mu \mathrm{g}$ : vit. $\mathrm{B}_{12} 16$

${ }^{2}$ diets (control or soyabean hulls diet) were supplemented with: sulphates (10, 90, 100 and 12.5 $\mathrm{mg} / \mathrm{kg}$ of supplemental $\mathrm{Cu}, \mathrm{Fe}, \mathrm{Zn}$ and $\mathrm{Mn}$, respectively, from sulphate forms); or chelated $(6,25$, 38 and $10 \mathrm{mg} / \mathrm{kg}$ of supplemental $\mathrm{Cu}, \mathrm{Fe}, \mathrm{Zn}$ and $\mathrm{Mn}$, respectively, from metal-amino acid chelated forms); both in sulphate and chelate minerals $0.3 \mathrm{mg} \mathrm{Se}$ (as $\mathrm{NaSeO}_{3}$ ) and $0.2 \mathrm{mg} \mathrm{I}$ (as $\mathrm{KI}$ ) were provided per kg of complete diet

${ }^{3}$ non-starch polysaccharides (NSP) was calculated as organic matter - (crude protein + crude fat + starch + sugar) 


\section{Experiment 2. Metabolism experiment}

Experimental design, animals, housing and diets. Four barrows (initially $25.6 \pm 0.1 \mathrm{~kg}$ of $\mathrm{BW}$ ) were used in a $4 \times 4$ Latin square design experiment to assess the effects of soyabean hulls and MAC on noxious gas emission from faeces and slurry. The pigs were housed in individual elevated solid-sided stainless steel metabolism cages $\left(1.6 \times 0.8 \mathrm{~m}^{2}\right)$ equipped with plastic slatted floors, stainless steel feeders, and low-pressure, automatic water nipple drinkers. Temperature was maintained at approximately $25^{\circ} \mathrm{C}$ with thermostatically controlled heaters and exhaust fans.

Sampling and measurements. During each experimental period, pigs were fed experimental diets for the first $7 \mathrm{~d}$, thereafter the collection of urine and faeces was initiated at 08.00 on $\mathrm{d} 8$. Urine and faeces samples were collected for $24 \mathrm{~h}$ and stored immediately after collection at $-20^{\circ} \mathrm{C}$. There is a $6-\mathrm{d}$ (from $\mathrm{d} 9$ to $\mathrm{d} 14$ ) convalescent period before introducing new experimental diets to pigs. During this convalescent period, all the pigs were fed control diets. At the conclusion of the experiment, urine and faeces samples were thawed, pooled within pig and period, and well-mixed. According to the method of Cho et al. (2008), subsamples of faeces $(300 \mathrm{~g})$ and slurry (150 g faeces and $150 \mathrm{~g}$ of urine were mixed well, 1:1, $\mathrm{wt} / \mathrm{wt}$; wet weight basis) were taken and stored in 2.61 plastic boxes in duplicate. Each box had a small hole in the middle of one side wall, which was sealed with adhesive plaster. The samples were permitted to ferment for $5 \mathrm{~d}$ at room temperature $\left(25^{\circ} \mathrm{C}\right)$. After the fermentation period, a Gastec (model GV-100) gas sampling pump was utilized for gas detection (Gastec Corp., Gastec detector tube No. $3 \mathrm{M}$ and $3 \mathrm{La}$ for $\mathrm{NH}_{3}$; No. $4 \mathrm{LL}$ and $4 \mathrm{LK}$ for $\mathrm{H}_{2} \mathrm{~S}$; No. 70 and $70 \mathrm{~L}$ for R.SH, Gastec Corp, detector tube, Japan). Prior to the measurements, slurry samples were shaken manually for approximately $30 \mathrm{~s}$ in order to disrupt any crust formation on the surface of the slurry sample and to homogenize them. The adhesive plasters were punctured, and $100 \mathrm{ml}$ of headspace air was sampled approximately $2.0 \mathrm{~cm}$ above the faeces or slurry surface. The gas emission of the sample within pig and period was averaged by measurements of two duplicate boxes.

\section{Statistical analyses}

In Experiment 1, the data were analysed as a $2 \times 2$ factorial using the General Linear Model Procedure of the SAS (1996). The model utilized included the effects of soyabean hulls and metal-amino acid chelated mineral, as well as the associated two-way interaction. The individual pen served as the unit. In Experiment 2, the data were analysed as $4 \times 4$ Latin square design using the General Linear Model Procedure of the SAS (1996). The variability of all the data was expressed as the standard error (SE) and a probability level of $\mathrm{P}<0.05$ was considered to be statistically significant, whereas $\mathrm{P}<0.10$ was considered to represent a tendency. 


\section{RESULTS}

Table 2 provides the results of supplemental soyabean hulls and MAC on growth performance in growing pigs. No soyabean hulls or MAC effects, as well as interaction between soyabean hulls and MAC were found on ADG, ADFI and gain/feed in our data.

Table 2. Effect of experimental treatments on growth performance in pigs ${ }^{1}$

\begin{tabular}{|c|c|c|c|c|c|}
\hline Diet & \multicolumn{2}{|c|}{ Control diet $^{1}$} & \multicolumn{2}{|c|}{ Soyabean hulls diet ${ }^{1}$} & \multirow{2}{*}{$\mathrm{SE}^{2}$} \\
\hline Minerals & sulphates & chelated & sulphates & chelated & \\
\hline $\mathrm{ADG}, \mathrm{kg}$ & 0.755 & 0.768 & 0.753 & 0.780 & 0.260 \\
\hline ADFI, kg & 1.498 & 1.478 & 1.502 & 1.521 & 0.235 \\
\hline $\mathrm{G} / \mathrm{F}, \mathrm{kg} / \mathrm{kg}$ & 0.504 & 0.520 & 0.501 & 0.512 & 0.042 \\
\hline
\end{tabular}

${ }^{1}$ control: basal diet; soyabean hulls diet: $50 \mathrm{~g} / \mathrm{kg}$ soyabean hulls included diet; sulphates: supplement sulphate minerals; chelated: supplement metal-amino acid chelate minerals ${ }^{2}$ pooled standard error

Apparent digestibility coefficients of supplemented diets are given in Table 3. We noted no significant soyabean hulls or MAC effects, as well as their interaction on DM and $\mathrm{N}$ digestibilities.

Table 3. Effect of experimental treatments on total tract apparent digestibility of DM and $\mathrm{N}$ in growing pigs

\begin{tabular}{|c|c|c|c|c|c|}
\hline Diet & Con & $\operatorname{diet}^{1}$ & Soyabe & $11 \mathrm{~s} \operatorname{diet}^{1}$ & $\mathrm{SF}^{2}$ \\
\hline Minerals & sulphates & chelated & sulphates & chelated & $\mathrm{SL}$ \\
\hline DM & 0.788 & 0.798 & 0.794 & 0.790 & 0.008 \\
\hline $\mathrm{N}$ & 0.814 & 0.809 & 0.815 & 0.814 & 0.012 \\
\hline
\end{tabular}

${ }_{1,2}$ see Table 2

The effects of dietary soyabean hulls and MAC supplementation on faecal and slurry noxious gas emission are shown in Table 4. Pigs fed on soyabean hulls diets tend to evidence lower faecal $\mathrm{NH}_{3}$ emission $(\mathrm{P}=0.09)$ as compared to those fed on control diets, however, slurry $\mathrm{NH}_{3}$ emission was unaffected by soyabean hulls diets $(\mathrm{P}=0.12)$. Metal-amino acid chelated mineral supplementation had no effect on $\mathrm{NH}_{3}$ emission from faeces and slurry. A significant level of interaction between soyabean hulls and MAC was observed in the $\mathrm{NH}_{3}$ emission from both the faeces and slurry $(\mathrm{P}=0.05, \mathrm{P}=0.01)$. Pigs fed on soyabean hulls diets tend to exhibit lower levels of $\mathrm{H}_{2} \mathrm{~S}$ emission in slurry $(\mathrm{P}=0.07)$, but evidenced lower levels of $\mathrm{H}_{2} \mathrm{~S}$ emission from both faeces and slurry $(\mathrm{P}=0.004, \mathrm{P}=0.02)$ when pigs were fed on a MAC-supplemented diet. The observed interaction between soyabean hulls and MAC was not observed in the $\mathrm{H}_{2} \mathrm{~S}$ emission. Metal-amino acid chelated mineral supplementation treatments resulted in a significant reduction 
$(\mathrm{P}=0.02)$ of mercaptans (R.SH) emission from faeces but did not from slurry, and no soyabean hulls effects as well as their interaction were observed in relation to R.SH emission.

Table 4. Effect of experimental treatments on noxious gas emission in pigs

\begin{tabular}{|c|c|c|c|c|c|}
\hline \multirow{2}{*}{$\begin{array}{l}\text { Diet } \\
\text { Minerals } \\
\end{array}$} & \multicolumn{2}{|c|}{ Control diet ${ }^{1}$} & \multicolumn{2}{|c|}{ Soyabean hulls diet ${ }^{1}$} & \multirow{2}{*}{$\mathrm{SE}^{2}$} \\
\hline & sulphates & chelated & sulphates & chelated & \\
\hline \multicolumn{6}{|l|}{$\mathrm{NH}_{3}, \mathrm{ppm}$} \\
\hline faeces $^{3,5,7}$ & 22.15 & 20.20 & 19.90 & 20.38 & 0.57 \\
\hline slurry ${ }^{4,7}$ & 74.75 & 65.00 & 64.50 & 68.00 & 2.14 \\
\hline \multicolumn{6}{|l|}{$\mathrm{H}_{2} \mathrm{~S}, \mathrm{ppm}$} \\
\hline faeces $^{6}$ & 11.10 & 9.88 & 11.18 & 10.30 & 0.30 \\
\hline slurry 5,6 & 6.30 & 5.73 & 5.85 & 5.40 & 0.20 \\
\hline \multicolumn{6}{|l|}{ R.SH, ppm } \\
\hline faeces $^{6}$ & 6.35 & 4.95 & 6.28 & 5.05 & 0.49 \\
\hline slurry & 11.80 & 11.00 & 11.08 & 11.00 & 0.99 \\
\hline
\end{tabular}

${ }^{1,2}$ see Table 2

${ }^{3}$ faeces $300 \mathrm{~g}$ kept in sealed box fermented $5 \mathrm{~d}$, using Gastec detector measure noxious gas emission

${ }^{4}$ faeces $150 \mathrm{~g}$ and urine $150 \mathrm{~g}$ kept in sealed box fermented $5 \mathrm{~d}$, using Gastec detector measure noxious gas emission

${ }^{5}$ soyabean hulls effect, $\mathrm{P}<0.10$

${ }^{6} \mathrm{MAC}$ effect, $\mathrm{P}<0.05$

${ }^{7}$ soyabean hulls $\times$ MAC interaction, $\mathrm{P}<0.05$

\section{DISCUSSION}

Previous reports regarding different NSP supplementation methods in pig diets have presented a variety of results. Radar matrix (1996) and Van Oeckel (1998) detected no effects on pig performance when 5 and $15 \%$ soyabean hulls as the primary NSP resource were added into the diets of growing and finishing pigs, respectively. Our results verified their findings. On the contrary, studies conducted by DeCamp et al. (2001) indicated that the addition of $10 \%$ soyabean hulls (the main NSP resource) with the addition of animal fat in the diets of finishing pigs could improve ADG and gain/feed characteristics. They explained that this might be attributable to the elevated fat in the soyabean hulls diet, thereby possibly augmenting growth for those pigs fed on diets containing soyabean hulls. Varel and Yen (1997) reviewed that the fermentation of NSP and dietary fibre take place in the caecum and colon of monogastric animals, and the produced VFA reduced the $\mathrm{pH}$ of the slurry. The effects of MAC on growth performance were assessed by a host of researchers. Creech et al. (2004) previously reported that 
trace mineral sources exerted no effects on performance during the growing or gilt development phase. Coffey et al. (1994) and Zhou et al. (1994) previously reported that additions of $\mathrm{Cu}$ from copper-lysine complexes resulted in improved pig performance as compared with copper sulphate. Other researchers, however, have noted no differences in growth-promoting activity between the two $\mathrm{Cu}$ sources (van Heugten and Coffey, 1992).

Both DM and $\mathrm{N}$ digestibilities were not affected in soyabean hulls treatments as compared to control treatments in the current study. However, in a previous study conducted by O'Connell et al. (2005), it was reported that the DM and $\mathrm{N}$ digestibilities were apparently reduced in their soyabean hulls treatment as compared to the control treatment. Another study conducted by Dilger et al. (2004) also reported that the apparent ileal digestibility of DM decreased in a linear fashion with increasing levels of added soyabean hulls (3 to 9\%), whereas $\mathrm{N}$ digestibility remained unaffected in $35-\mathrm{kg}$ barrows. These different results might be attributable to two possible factors. Firstly, slowed gastrointestinal emptying may occur in response to dietary fibre content and types as well as viscous material (Guérin et al., 2001). Secondly, gastrointestinal pH may be increased as the result of the buffering capacity of NSP, with the indirect result of reduction in gastrin secretion in response to the more alkaline environment (Dilger et al., 2004). Metalamino acid chelated mineral has been shown to evidence better absorption, which has been reported by many researchers to enhance the efficiency of its use (Yu et al., 2000; Guo et al., 2001). However, our data evidenced no improvements in the MAC treatments, the different supplemented level and mineral type from that utilized in other experiments may be a reasonable explanation for the differences observed in the current study.

Supplementing pig diets with high NSP sources coupled with the addition of amino acids has been suggested as a way to activate the intestinal microbiota ecosystem, and also alters excreta $\mathrm{pH}$, thereby reducing the emission of $\mathrm{NH}_{3}$ from the faeces. Our data indicated that $\mathrm{NH}_{3}$ emission from both the faeces and slurry were reduced significantly as the result of the addition of soyabean hulls (primary NSP resources). This result is consistent with the findings of previous research. Mroz et al. (2000) determined that the addition of soyabean hulls $(25 \%)$ and (or) sugar beet pulp (25\%) reduced the ratio of urinary:faecal N, and thereby the emission of $\mathrm{NH}_{3}$ from the slurry in finishing pigs. Hansen et al. (2007) observed 30\% reduced $\mathrm{NH}_{3}$ emission in 15\% inulin (a known NSP resource) addition treatment in finishing pigs. The possible reasons for the reduction in $\mathrm{NH}_{3}$ emission may be attributable to the beneficial effects of NSP on the bifidobacteria and lactobacilli populations present in the large intestine, as the inclusion of NSP in the diet promotes carbohydrate-fermenting bacteria (O'Connell et al., 2005). In the large intestine, these fibre-degrading bacteria utilize $\mathrm{NH}_{3}$ as a substrate for microbial protein synthesis and are subsequently excreted in the faeces. Such 
effects shift nitrogen excretion from volatile $\mathrm{NH}_{3}$ in the urine to bacterial nitrogen in the faeces. This is desirable, as it limits the capacity for rapid $\mathrm{NH}_{3}$ volatilization (Nahm, 2003). The interaction between soyabean hulls and MAC may be attributable to the fact that MAC exerts some additional effects on the activation of the intestinal bacteria ecosystem. Our current experiment was not designed to determine the changes of intestinal bacteria population. Further work should be conducted in order to investigate the clear relationship between soyabean hulls and dietary MAC supplementation.

Hydrogen sulphide and R.SH are crucial sulphur-containing volatile constituents (Spoelstra, 1980). Variations in sulpuric odorous compound concentrations in animal faeces are principally attributable to the differences in the sulphur composition of diets fed to pigs, and the metabolism of sulphur-containing amino acids (methionine, cystine and cysteine), which generate sulphuric odorous compounds including $\mathrm{H}_{2} \mathrm{~S}$ and R.SH (Reviere et al., 1974; Kiene and Hines, 1995). Our data indicated that faecal $\mathrm{H}_{2} \mathrm{~S}$ emission was increased as the result of soyabean hulls supplementation. Similarly, in our previous study, we detected a linear increase in $\mathrm{H}_{2} \mathrm{~S}$ emission when increasing the level of soyabean hulls addition in the diets of growing pigs (unpublished). High dietary NSP levels resulted in a reduction in CP levels and enhanced microbial activities within the gut of the animal and in the slurry stores, which might be responsible for the higher observed slurry VFA concentrations and lower $\mathrm{pH}$. Low slurry $\mathrm{pH}$ can inhibit $\mathrm{H}_{2} \mathrm{~S}$ emission. Our data are inconsistent with the findings of DeCamp et al. (2001), who reported that $\mathrm{H}_{2} \mathrm{~S}$ emission in room air samples was decreased significantly when finishing pigs were fed on a diet containing $10 \%$ soyabean hulls as compared with those fed on a control diet. The difference between our results and those of others may be attributable to the different cysteine and cystine levels in the diets. Metal-amino acid chelate mineral treatments resulted in lower sulphur compositions than were observed with sulphate mineral diets, due to the lack of $\mathrm{SO}_{4}^{2-}$. Again, sulphuric odorous compound concentrations in animal faeces were found to be due principally to the differences in the level of sulphuric compositions in the diets fed to the pigs. Therefore, lower $\mathrm{H}_{2} \mathrm{~S}$ emission in both faeces and slurry were obtained in the current experiment.

\section{CONCLUSIONS}

We conclude that the interaction between dietary soyabean hulls and MAC performs a function in noxious gas emission. Ammonia emission from pig faeces can be substantially reduced via the administration of a soyabean hulls to diet. Hydrogen sulphide emission from pig faeces and slurry could be reduced by MAC supplementation. The interaction observed in slurry $\mathrm{NH}_{3}$ emission in the 
current experiment may be attributed to some additional urinary $\mathrm{H}_{2} \mathrm{~S}$ emission lowering effects. The precise mechanisms underlying this interaction require further investigation.

\section{REFERENCES}

AOAC, 1995. Association of Official Analytical Chemists, Official Method of Analysis. 16th Edition. Washington, DC

Cho J.H., Chen Y.J., Min B.J., Yoo J.S., Wang Y., Kim I.H., 2008. Effects of reducing dietary crude protein on growth performance, odor gas emission from manure and blood urea nitrogen and IGF-1 concentrations of serum in nursery pigs. Anim. Sci. J. (in press)

Coffey R.D., Cromwell G.L., Monegue H.J., 1994. Efficacy of a copper-lysine complex as a growth promotant for weanling pigs. J. Anim. Sci. 72, 2880-2892

Creech B.L., Spears J.W., Flowers W.L., Hill G.M., Lloyd K.E., Armstrong T.A., Engle T.E., 2004. Effect of dietary trace mineral concentration and source (inorganic vs. chelated) on performance, mineral status, and faecal mineral excretion in pigs from weaning through finishing. J. Anim. Sci. 82, 2140-2147

DeCamp S.A., Hill B.E., Hankins S.L., Bundy D.C., Powers W.J., 2001. Effects of soybean hulls in commercial diet on pig performance, manure composition, and selected air quality parameters in swine facilities. J. Anim. Sci. 79, Suppl. 1, 252 (Abstr.)

Dilger R.N., Sands J.S., Ragland D., Adeola O., 2004. Digestibility of nitrogen and amino acids in soybean meal with added soyhulls. J. Anim. Sci. 82, 715-724

Ferket P.R., Heugten E.V., Kempen T.A.V., Angel R., 2002. Nutritional strategies to reduce environmental emission from non ruminants. J. Anim. Sci. 80, Suppl. 2, 168-182

Guerin S., Ramonet Y., LeCloarec J., Meunier-Salaün M.C., Bourguet P., Malbert C.H., 2001. Dietary fibres reduced gastric emptying rate as a consequence of impaired distal stomach function in conscious pig. Brit. J. Nutr. 85, 343-350

Guo R., Henry P.R., Holwerda R.A., Cao J., Littell R.C., Miles R.D., Ammerman C.B., 2001. Chemical characteristics and relative bioavailability of supplemental organic copper sources for poultry. J. Anim. Sci. 79, 1132-1141

Hansen C.F., Sørensen G., Lyngbye M., 2007. Reduced diet crude protein level, benzoic acid and inulin reduced ammonia, but failed to influence odour emission from finishing pigs. Livest. Sci. $109,228-231$

Kiene R.P., Hines M.E., 1995. Microbial formation of dimethyl sulfide in anoxic Sphagnum peat. Appl. Environ. Microbiol. 61, 2720-2726

Kline R.D., Hays V.W., Cromwell G.L., 1971. Effects of copper, molybdenum and sulfate on performance, hematology and copper stores of pigs and lambs. J. Anim. Sci. 33, 771-778

Mroz Z., Moeser A.J., Vreman K., vanDiepen J.T.M., vanKempen T., Canh T.T., Jongbloed A.W., 2000. Effects of dietary carbohydrates and buffering capacity on nutrient digestibility and manure characteristics in finishing pigs. J. Anim. Sci. 78, 3096-3106

Nahm K.H., 2003. Influence of fermentable carbohydrates on shifting nitrogen excretion and reducing ammonia emission of pigs. Crit. Rev. Environ. Sci. Tech. 30, 165-186

NRC, 1998. Nutrient Requirement of Pigs. 10th Edition. National Research Council, Academy Press. Washington, DC

O'Connell J.M., Callan J.J., Sweeney T., O'Doherty J.V., 2005. The effect of cereal type and exogenous enzyme supplementation in pig diets on nutrient digestibility, intestinal microflora, 
volatile fatty acid concentration and manure ammonia emission from finisher pigs. Anim. Sci. 81, 357-364

Radar matrix, 1996. Feed Table 28/05/1996, Radar NV, Dorpstraat 4, B-9800 Deinze (Belgium)

Reviere J., Subtil J.C., Catroux G., 1974. Etude de l'évolution physico-chiminique et microbiologique du lisier de porcs pendant le stockage anaerobie. Ann. Agronom. 25, 383-401

SAS, 1996. SAS User's Guide. Release 6.12 Edition. SAS Institute Inc. Cary, NC

Schiffman S.S., 1998. Livestock odors: Implications for human health and well-being. J. Anim. Sci. $76,1343-1355$

Spoelstra S.F., 1980. Origin of objectionable odorous components in piggery wastes and the possibility of applying indicator components for studying odor development. Agr. Environ. 5, 241-260

Van Heugten E., Coffey M.T., 1992. Efficacy of a copper-lysine chelate as growth promotant in weanling swine. J. Anim. Sci. 70, Suppl. 1, 18 (Abstr.)

Van Oeckel M.J., Warnants N., De Paepe M., Casteels M., Boucque Ch.V., 1998. Effect of fibre-rich diets on the backfat skatole content of entire male pigs. Livest. Prod. Sci. 56, 173-180

Varel V.H., Yen J.T., 1997. Microbial perspective on fiber utilization by swine. J. Anim. Sci. 75, 2715-2722

Williams C.H., David D.J., Iismaa O., 1962. The determination of chromic oxide in faeces samples by atomic absorption spectrophotometry. J. Agr. Sci. 59, 381-385

Yu B., Huang W.J., Chiou P.W., 2000. Bioavailability of iron from amino acid complex in weanling pigs. Anim. Feed Sci. Tech. 86, 39-52

Zhou W., Kornegay E.T., van Leer H., Swinkels J.W.G.M., Wong E.A., Lindemann M.D., 1994. The role of feed consumption and feed efficiency in copper-stimulated growth. J. Anim. Sci. 72, 2385-2394 